\section{Photoperiod and Photosynthetic Photon Flux Influence Growth and Quality of Greenhouse-grown Lettuce}

\author{
Linda Gaudreau and Josée Charbonneau \\ Département de Phytologie, Centre de Recherche en Horticulture, Université \\ Laval, Québec, Qué. G1K 7P4, Canada \\ Louis-Philippe Vézina \\ Research Station, Agriculture Canda, Sainte-Foy, Qué. G1V2J3, Canada
}

\author{
André Gosselin \\ Département de Phytologie, Centre de Recherche en Horticulture, Université \\ Laval, Québec, Qué. G1K 7P4, Canada
}

Additional index words. Lactuca sativa, light, tipburn

\begin{abstract}
Karlo' and 'Rosana', two Boston-type lettuce (Lactuca sativa L.) cultivars, were subjected to various light treatments in greenhouses equipped with one of two propane heating systems. Photoperiods of 16, 20, 24, or 24 hours for 2 weeks after transplanting and then 16 hours (24-16) and photosynthetic photon flux of 50 or $100 \mu \mathrm{mol} \cdot \mathrm{m}^{-2} \cdot \mathrm{s}^{-1}$ provided by supplementary lighting (high-pressure sodium vapor lamps) were compared to natural light during four experiments performed in greenhouses between Sept. 1989 and May 1990. Using supplementary lighting resulted in significant increases in biomass $(\leq 270 \%)$, head firmness, and tipburn incidence and decreases in production cycle length $(\approx 30 \%)$. Treatment effects were most pronounced during the months when natural-light levels were low. Fresh weights were higher for 'Karlo' than 'Rosana'; however, 'Rosana' was less susceptible to tipburn than 'Karlo'. In general, the radiant heating system resulted in earlier crop maturity and a higher incidence of tipburn than the hot-air system.
\end{abstract}

In 1988, the total greenhouse area devoted to vegetable production in Quebec was $\approx 80$ ha. Lettuce accounted for $\approx 5 \%$ of that area, and the crop's value was estimated at between 4 and 5 million dollars. Greenhouse-grown lettuce production has expanded substantially in recent years. Formerly, lettuce was grown mainly as a subsidiary crop; today, it is grown increasingly as a main crop. This phenomenon is particularly noteworthy for Boston lettuce.

Heating costs in winter represent a large fraction of production costs. Roltz and Heins (1982) showed that a radiant heating system can yield energy savings. However, to our knowledge, no one has studied the effects of infrared radiation on plant growth and development of hydroponically grown lettuce.

Light is regarded as a primary factor regulating plant growth and development. Demers et al. (1990) and Dorais et al. (1990) showed that using high-energy lighting conditions increased productivity for various greenhousegrown vegetables. Increases in dry weight (Knight and Mitchell, 1983) and relative plant growth rates in lettuce (Knight and Mitchell, 1983, 1988) under high-energy lighting con-

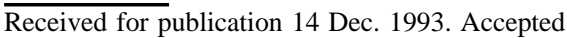
for publication 14 May 1994. We wish to thank the Natural Sciences and Engineering Research Council of Canada and ICG Gaz for their financial support, and Sylvain Larouche and René Pouliot for their technical assistance. The cost of publishing this paper was defrayed in part by the payment of page charges. Under postal regulations, this paper therefore must be hereby marked advertisement solely to indicate this fact.
}

ditions have been reported in experiments conducted in growth chambers. Lengthening the photoperiod has resulted in substantial increases in fresh weight for various lettuce cultivars (Koontz and Prince, 1986). Maximum production cycle length occurs at the time when natural light is weakest (Glenn, 1984).

Light conditions also affect lettuce quality by influencing the incidence of tipburn (Tibbitts and Rao, 1968) and the heading process (Benoît, 1987). Tipburn, which appears during head formation, is a disorder associated with low calcium levels and causes young leaves to become brown and to have necrosis beginning at the leaf margins (Collier and Tibbitts, 1982). It is associated with environmental conditions conducive to the rapid accumulation of dry matter (Cox et al., 1976). Head formation is a major standard of lettuce quality (van Holsteijn, 1980) and is stimulated by suitable light and temperature conditions (Maaswinkel and Welles, 1987).

Our objectives were to assess the influence of two propane heating systems on lettuce plant development and to quantify the effects of long photoperiods and high photosynthetic photon flux (PPF) levels on greenhouse-grown lettuce growth and quality.

\section{Materials and Methods}

'Karlo' and 'Rosana' lettuce seeds were sown in LC-1 Hortcubes (Smithes-Oasis, Kent, Ohio) on four dates (Table 1). 'Karlo' and 'Rosana', a short- and long-day cultivar, re- spectively, were used to determine to what extent a long-day cultivar could adapt to supplementary lighting during the low natural-light intensity period. At the third true-leaf stage, the lettuce plants were transplanted at 30 plants/ $\mathrm{m}^{2}$ into a recirculating-solution, hydroponic culture system with $2.4-\mathrm{m}$-long $\times 8.3-\mathrm{cm}-$ wide troughs. The experiment was conducted in four greenhouses, each $70 \mathrm{~m}^{2}$ and covered with a double polyethylene film on the roof and a double polycarbonate film on the sides. Two of these greenhouses were equipped with catalytic-combustion, radiant heating systems (Catalor, Torino, Italy), and the other two were heated with conventional propane-fired space heaters. The $\mathrm{CO}_{2}$ concentration was maintained at $1000 \pm 50 \mathrm{ppm}$. The plants were subjected to one of three PPF $(0,50$, or 100 $\mu \mathrm{mol} \cdot \mathrm{m}^{-2} \cdot \mathrm{s}^{-1}$ ) provided by high-pressure, sodium vapor lamps (PL 90; P.L. Lighting Systems, St. Catherines, Ont., Canada). Photoperiods extended to $16,20,24$, and 24-16 h (i.e., $24 \mathrm{~h}$ during the first 2 weeks after transplanting and $16 \mathrm{~h}$ during the subsequent weeks) were compared to the natural photoperiod for four trials conducted between Sept. 1989 and May 1990.

A complete nutrient solution containing $\left(\mathrm{mmol}^{\circ}\right.$ liter $^{-1}$ ) 8.5 N, 0.78 P, 4.4 K, 2.9 Ca, and 1.2 $\mathrm{Mg}$ and ( $\mu$ mol.liter $\left.{ }^{-1}\right) 71 \mathrm{Fe}, 18 \mathrm{Mn}, 6.1$ $\mathrm{Zn}, 0.4 \mathrm{Cu}, 26.8 \mathrm{~B}$, and $0.6 \mathrm{Mo}$ was used for all four experiments. The $\mathrm{pH}$ of the nutrient solution was checked daily and, if necessary, adjusted to 6.0. Electric conductivity was maintained at $1.5 \mathrm{mS} \cdot \mathrm{cm}^{-1}$. The temperature of the nutrient solution was maintained at $18 \mathrm{C}$.

The ambient temperature during the day was kept at $16 \mathrm{C}$, and fans were activated when the temperature rose to 20C. Nights were at $12 \mathrm{C}$ in compartments heated by space heaters and $9 \mathrm{C}$ for compartments in which catalytic radiant panels were used. For purposes of the described conditions, night was deemed to begin at 6:00 PM and to end at 8:00 AM.

A nested experimental design was adopted, with the two heating systems as the main plots, the five light treatments (comprised of the three light levels and the two photoperiods) as subplots, and the two cultivars as sub-subplots. The treatments were randomly distributed within two replications. Homogeneity of variance was checked by a Bartlett test, and logarithmic and square-root transformations were performed to ensure such homogeneity for Expts. 1-3 (Table 1). Differences between treatments were determined by analyses of variance and orthogonal comparisons.

Measurements of aerial biomass were taken every week on five plants per light treatment, beginning the first week after transplanting. Tipburn and head firmness were rated on a scale from 0 to 5 at the time of harvest. For tipburn, a rating higher than 1 meant that the lettuce in question was not marketable. Head firmness was assessed by tactile pressure where $1=$ absence of heading and $5=$ a very firm head of lettuce.

\section{Results}

Heating system. More biomass was produced with the radiant heating than with the air 
Table 1. Timetable used for the four experiments.

\begin{tabular}{|c|c|c|c|c|c|}
\hline \multirow[b]{2}{*}{ Expt. } & \multicolumn{2}{|c|}{ Supplementary lighting treatments } & \multirow[b]{2}{*}{ Planting date } & \multirow[b]{2}{*}{ Transplanting date } & \multirow[b]{2}{*}{ Observation period } \\
\hline & $\mathrm{PPF}\left(\mu \mathrm{mol} \cdot \mathrm{m}^{-2} \cdot \mathrm{s}^{-1}\right)$ & Duration $(\mathrm{h})$ & & & \\
\hline 1 & $0,50,100$ & $16,24-16^{2}$ & 18 Sept. 1989 & 3 Oct. 1989 & 10 Oct. 1989 to 14 Nov. 1989 \\
\hline 2 & $0,50,100$ & 16,24 & 7 Nov. 1989 & 28 Nov. 1989 & 5 Dec. 1989 to 16 Jan. 1990 \\
\hline 3 & $0,50,100$ & 16,20 & 2 Jan. 1990 & 25 Jan. 1990 & 1 Feb. 1990 to 15 Mar. 1990 \\
\hline 4 & $0,50,100$ & $16,24-16$ & 8 Mar. 1990 & 28 Mar. 1990 & 4 Apr. 1990 to 9 May 1990 \\
\hline
\end{tabular}

${ }^{\mathrm{z}}$ Photoperiod $=24 \mathrm{~h}$ during the first 2 weeks after transplanting and $16 \mathrm{~h}$ during subsequent weeks.

heater system in Expts. 2 and 3, which ran from November to March (Table 2). With the radiant heating system, we measured substantial increases in crop fresh weight in Expt. 2. The impact of the heating system was negligible in Expts. 1 and 4, planted in September and March, respectively, because higher outdoor temperatures at that time of year meant that less heat was required to keep the greenhouses suitably warm.

In general, using a radiant heating system was associated with higher tipburn ratings than the air-heated system (Table 2). For 'Karlo', radiant heating resulted in considerable increases in tipburn rating, particularly in Expt. 2.

Most heads were rated firmer for plants cultivated in greenhouses equipped with radiant heating systems. The impact of the heating system was more pronounced in experiments performed between November and March (Expts. 3 and 4; Table 2).

Supplementarylighting and cultivars. Fresh weights were significantly higher for 'Karlo' than for 'Rosana' in all experiments (Table 3). Plants receiving supplementary lighting produced significantly more biomass than the control in all four experiments. The differences were greatest in Expts. 1-3, which were performed at the time of year when solar radiation was weakest.

In Expt. 1, lettuce plants receiving supplementary lighting reached the harvest stage $(150 \mathrm{~g}) 6$ weeks after being transplanted, but the control plants did not. 'Karlo' and 'Rosana' plants receiving a $24-\mathrm{h}$ rather than a $16-\mathrm{h}$ photoperiod during the first 2 weeks produced significantly more aerial biomass $(16 \%$ and $17 \%$, respectively, for a PPF of $50 \mu \mathrm{mol} \cdot \mathrm{m}^{-2} \cdot \mathrm{s}^{-1}$; $19 \%$ and $23 \%$, respectively, for a PPF of $\left.100 \mu \mathrm{mol} \cdot \mathrm{m}^{-2} \cdot \mathrm{s}^{-1}\right)$.

Using a PPF of $100 \mu \mathrm{mol} \cdot \mathrm{m}^{-2} \cdot \mathrm{s}^{-1}$ reduced the crop cycle by 14 days compared to the control treatment in Expt. 2. A PPF of 100 rather than $50 \mu \mathrm{mol} \cdot \mathrm{m}^{-2} \cdot \mathrm{s}^{-1}$ produced more biomass with a $16-\mathrm{h}$ rather than a $24-\mathrm{h}$ photoperiod.
In Expt. 3, using a 20-h compared to a 16$\mathrm{h}$ photoperiod with PPF values of 50 or 100 $\mu \mathrm{mol} \cdot \mathrm{m}^{-2} \cdot \mathrm{s}^{-1}$ resulted in a $15 \%$ and $23 \%$ increase, respectively, in harvested 'Karlo' biomass and a $23 \%$ and $19 \%$, respectively, increase in harvested 'Rosana' biomass (Table 3).

In Expt. 4 , using a $100 \mu \mathrm{mol} \cdot \mathrm{m}^{-2} \cdot \mathrm{s}^{-1} \mathrm{PPF}$ and a photoperiod of 24-16 h produced biomasses that were $35 \%$ larger for 'Karlo' and $25 \%$ larger for 'Rosana' compared to the control treatment (Table 3). As the intensity of natural light grew steadily with the advancing season, the increases in fresh weight resulting from supplementary lighting were not as great as those obtained in the previous experiments.

Tipburn was more severe with 'Karlo' than with 'Rosana', especially in Expt. 4 (i.e., at the time of year when solar radiation increased substantially) (Table 4). High light conditions resulted in even greater tipburn development compared to control plants. High PPF increased tipburn more than a long photoperiod.

In Expt. 1, tipburn was severe in 'Karlo' lettuce plants exposed to $100 \mu \mathrm{mol} \cdot \mathrm{m}^{-2} \cdot \mathrm{s}^{-1}$ with a 24-16-h photoperiod (Table 4); $12 \%$ of the lettuce was nonmarketable (Table 5). In Expt. 2, 'Karlo' lettuce was more susceptible to tipburn development than in the previous experiment (Table 4). Using a 24-h rather than a 16-h photoperiod resulted in $20 \%$ and $63 \%$ tipburn rating increases when PPF was 50 and $100 \mu \mathrm{mol} \cdot \mathrm{m}^{-2} \cdot \mathrm{s}^{-1}$, respectively. Tipburn was not severe under conditions of maximum light intensity and exposure.

Tipburn was more severe on 'Rosana' in Expt. 3 than in Expts. 1 and 2. Tipburn was highest under a PPF of $100 \mu \mathrm{mol} \cdot \mathrm{m}^{-2} \cdot \mathrm{s}^{-1}$ and a 20-h photoperiod. In Expt. 4, 'Karlo' at a PPF of 100 rather than $50 \mu \mathrm{mol} \cdot \mathrm{m}^{-2} \cdot \mathrm{s}^{-1}$ had a $14 \%$ and $35 \%$ increase in tipburn when the photoperiod was $16 \mathrm{~h}$ and $24-16 \mathrm{~h}$, respectively. With all light treatments, the percentages of nonmarketable 'Rosana', 'Karlo', and control specimens were $0 \%, 30 \%$, and $85 \%$, respectively, for plants exposed to $100 \mu \mathrm{mol} \cdot \mathrm{m}^{-2} \cdot \mathrm{s}^{-1}$ with either photoperiod (Table 5).
Heads were firmer for 'Karlo' than 'Rosana'. Supplementary lighting resulted in firmer heads than natural lighting in all experiments (Table 6). The impact of supplementary lighting waned as the season advanced and the natural light level rose. In Expt. 1, a 24-h photoperiod during the first 2 weeks produced firmer heads when PPF was 50 rather than 100 $\mu \mathrm{mol} \cdot \mathrm{m}^{-2} \cdot \mathrm{s}^{-1}$. In Expt. 2, the low natural light level produced soft lettuce heads, especially for 'Rosana'. For 'Karlo' lettuce, continuous lighting resulted in considerably firmer heads, particularly with $50 \mu \mathrm{mol} \cdot \mathrm{m}^{-2} \cdot \mathrm{s}^{-1}$.

In Expt. 3, head firmness ratings for 'Karlo' grown under a PPF of $50 \mu \mathrm{mol} \cdot \mathrm{m}^{-2} \cdot \mathrm{s}^{-1}$ with a 16-h photoperiod were $145 \%$ higher than for the control (Table 6). The 20-h photoperiod resulted in further increase in firmness, for both PPF and both cultivars. The head firmness increases observed with the various light treatments were less substantial in Expt. 4 (spring), presumably because of the much higher energy level of natural light at that time of year. Firmness ratings were 38\% and 14\% higher for 'Karlo' and 'Rosana', respectively, exposed to a PPF of $50 \mu \mathrm{mol} \cdot \mathrm{m}^{-2} \cdot \mathrm{s}^{-1}$ over a 16-h photoperiod than for the controls plants.

\section{Discussion}

Heating system. To our knowledge, no information is available on the impact of radiant heating on lettuce cultivation, but experiments have been performed on other species, such as tomatoes (Lycopersicon esculentum Mill) (Lacroix et al., 1971). Some investigators found that an infrared radiant heating system had no effect on fruit growth (Reist, 1983), yield, or quality (van de Burg et al., 1981), but others reported lower total yields for tomatoes (Lacroix et al., 1971). The increases in biomass using the radiant compared to the air-heated system may have resulted from higher leaf temperatures, higher levels of $\mathrm{CO}_{2}$, or higher relative humidity levels because of the combustion gases $\left(\mathrm{CO}_{2}, \mathrm{H}_{2} \mathrm{O}\right)$

Table 2. Effects of two heating systems on biomass, incidence of tipburn, and head firmness for 'Karlo' (K) and 'Rosana' (R) Boston-type lettuce 6 weeks after transplanting.

\begin{tabular}{|c|c|c|c|c|c|c|c|c|c|}
\hline \multirow[b]{2}{*}{ Characteristics } & \multirow{2}{*}{$\begin{array}{c}\text { Heating } \\
\text { system }\end{array}$} & \multicolumn{2}{|c|}{ Expt. $1^{2}$} & \multicolumn{2}{|c|}{ Expt. 2} & \multicolumn{2}{|c|}{ Expt. 3} & \multicolumn{2}{|c|}{ Expt. 4} \\
\hline & & K & $\mathrm{R}$ & $\mathrm{K}$ & $\mathrm{R}$ & $\mathrm{K}$ & $\mathrm{R}$ & $\mathrm{K}$ & $\mathrm{R}$ \\
\hline \multirow{2}{*}{ Biomass (g) } & Air heater & $150 \pm 8.7$ & $106 \pm 5.8$ & $115 \pm 7.9$ & $87 \pm 6.1$ & $182 \pm 8.1$ & $138 \pm 4.9$ & $247 \pm 6.4$ & $207 \pm 4.7$ \\
\hline & Radiant & $152 \pm 5.8$ & $115 \pm 4.7$ & $164 \pm 8.9$ & $138 \pm 5.8$ & $199 \pm 6.9$ & $159 \pm 6.0$ & $252 \pm 6.7$ & $186 \pm 4.2$ \\
\hline \multirow[t]{2}{*}{ Tipburn rating ${ }^{y}$} & Air heater & $0.0 \pm 0.0$ & $0.0 \pm 0.0$ & $0.3 \pm 0.1$ & $0.2 \pm 0.1$ & $1.1 \pm 0.2$ & $0.2 \pm 0.1$ & $1.5 \pm 0.2$ & $0.0 \pm 0.0$ \\
\hline & Radiant & $0.3 \pm 0.1$ & $0.0 \pm 0.0$ & $1.8 \pm 0.3$ & $0.5 \pm 0.2$ & $1.7 \pm 0.2$ & $1.6 \pm 0.2$ & $2.4 \pm 0.2$ & $0.1 \pm 0.0$ \\
\hline \multirow[t]{2}{*}{ Head firmness ${ }^{x}$} & Air heater & $3.5 \pm 0.2$ & $2.7 \pm 0.2$ & $1.3 \pm 0.2$ & $0.8 \pm 0.2$ & $3.0 \pm 0.2$ & $2.7 \pm 0.2$ & $4.5 \pm 0.1$ & $4.9 \pm 0.1$ \\
\hline & Radiant & $3.8 \pm 0.2$ & $3.1 \pm 0.2$ & $2.0 \pm 0.3$ & $2.0 \pm 0.3$ & $3.6 \pm 0.2$ & $3.4 \pm 0.3$ & $4.5 \pm 0.1$ & $4.5 \pm 0.1$ \\
\hline
\end{tabular}

${ }^{2}$ See Table 1 for the timetable used for the four experiments.

${ }^{y} \mathrm{~A}$ rating of 0 indicates no tipburn; 5 means that all the leaves were affected.

${ }^{\times}$Rated on a scale of 0 to 5 , where $0=$ absence of head formation and $5=$ very firm head. 
Table 3. Effects of various light treatments on biomass of 'Karlo' $(K)$ and 'Rosana' (R) Boston-type lettuce 6 weeks after transplanting.

\begin{tabular}{|c|c|c|c|c|c|c|c|c|c|c|}
\hline \multicolumn{3}{|c|}{ Supplementary lighting treatments } & \multicolumn{8}{|c|}{ Fresh biomass after 42 days ( $\mathrm{g} /$ plant) } \\
\hline \multirow{2}{*}{$\begin{array}{l}\text { Photoperiod } \\
\text { (h) }\end{array}$} & \multirow{2}{*}{\multicolumn{2}{|c|}{$\begin{array}{c}\mathrm{PPF} \\
\left(\mu \mathrm{mol} \cdot \mathrm{m}^{-2} \cdot \mathrm{s}^{-1}\right)\end{array}$}} & \multicolumn{2}{|c|}{ Expt. $1^{z}$} & \multicolumn{2}{|c|}{ Expt. 2} & \multicolumn{2}{|c|}{ Expt. 3} & \multicolumn{2}{|c|}{ Expt. 4} \\
\hline & & & $\mathrm{K}$ & $\mathrm{R}$ & $\mathrm{K}$ & $\mathrm{R}$ & $\mathrm{K}$ & $\mathrm{R}$ & $\mathrm{K}$ & $\mathrm{R}$ \\
\hline Control & Control 2 & & 83 & 64 & 59 & 59 & 123 & 101 & 205 & 173 \\
\hline \multirow[t]{2}{*}{16} & 50 & & 141 & 100 & 108 & 90 & 175 & 131 & 253 & 201 \\
\hline & 100 & & 167 & 123 & 168 & 134 & 211 & 160 & 256 & 211 \\
\hline \multirow[t]{2}{*}{20} & 50 & & --- & --- & --- & --- & 202 & 162 & --- & -- \\
\hline & 100 & & --- & --- & --- & --- & 241 & 189 & --- & --- \\
\hline \multirow[t]{2}{*}{$24-16^{y}$} & 50 & & 163 & 116 & --- & --- & --- & --- & 250 & 185 \\
\hline & 100 & & 199 & 151 & --- & --- & --- & --- & 280 & 214 \\
\hline \multirow[t]{3}{*}{24} & 50 & & --- & --- & 146 & 121 & --- & --- & --- & --- \\
\hline & 100 & & --- & --- & 218 & 160 & --- & --- & --- & --- \\
\hline & & $\underline{\mathrm{df}}$ & \multicolumn{8}{|c|}{ Mean squares } \\
\hline \multicolumn{2}{|l|}{ Heating } & $\overline{1}$ & \multicolumn{2}{|c|}{$0.0397^{x}$} & \multirow{2}{*}{\multicolumn{2}{|c|}{$276.84^{x}$}} & \multicolumn{2}{|c|}{$0.1421^{x}$} & \multicolumn{2}{|c|}{3391} \\
\hline \multicolumn{2}{|l|}{ Error a } & 1 & \multicolumn{2}{|c|}{0.0533} & & & \multirow{2}{*}{\multicolumn{2}{|c|}{0.0522}} & \multicolumn{2}{|c|}{30} \\
\hline \multicolumn{2}{|c|}{ Lighting } & 4 & \multirow{2}{*}{\multicolumn{2}{|c|}{$2.0639^{* *}$}} & \multirow{2}{*}{\multicolumn{2}{|c|}{$567.84^{* *}$}} & & & \multirow{2}{*}{\multicolumn{2}{|c|}{$5977^{* *}$}} \\
\hline \multicolumn{2}{|c|}{ Unlighted vs. lighted } & 1 & & & & & \multicolumn{2}{|c|}{$1.4397^{* *}$} & & \\
\hline 50 vs. 100 p & $\mathrm{m}^{-2} \cdot \mathrm{s}^{-1}$ & 1 & \multicolumn{2}{|c|}{$0.2865^{* *}$} & \multicolumn{2}{|c|}{$208.81^{* *}$} & \multicolumn{2}{|c|}{$0.2175^{*}$} & & \\
\hline $16 \mathrm{~h}$ vs. 20 , & 6 , or $24 \mathrm{~h}$ & 1 & & & & & & & & \\
\hline Error b & & 8 & & & & & & & & \\
\hline Cultivar & & 1 & & & & & & & & \\
\hline Heating $\times \mathrm{c}$ & & 1 & & & & & & & & \\
\hline Lighting $\times$ & & 4 & & & & & & & & \\
\hline
\end{tabular}

${ }^{2}$ See Table 1 for the timetable used for the four experiments.

${ }^{\mathrm{y}}$ Photoperiod $=24 \mathrm{~h}$ during the first 2 weeks after transplanting and $16 \mathrm{~h}$ during subsequent weeks.

'Insufficient number of degrees of freedom. The mean values appearing in this table have been calculated for the two heating systems combined.

ss, *** Nonsignificant or significant at $P \leq 0.05$ or 0.01 , respectively.

Table 4. Effects of various light treatments on incidence of tipburn for 'Karlo' (K) and 'Rosana' (R) Boston-type lettuce 6 weeks after transplanting.

\begin{tabular}{|c|c|c|c|c|c|c|c|c|c|c|}
\hline \multicolumn{3}{|c|}{ Supplementary lighting treatments } & \multicolumn{8}{|c|}{ Tipburn rating ${ }^{z}$} \\
\hline \multirow{2}{*}{$\begin{array}{l}\text { Photoperiod } \\
\text { (h) }\end{array}$} & \multirow{2}{*}{$\begin{array}{c}\text { PPF } \\
\left(\mu \mathrm{mol} \cdot \mathrm{m}^{-2} \cdot \mathrm{s}^{-1}\right)\end{array}$} & & \multicolumn{2}{|c|}{ Expt. $1^{y}$} & \multicolumn{2}{|c|}{ Expt. 2} & \multicolumn{2}{|c|}{ Expt. 3} & \multicolumn{2}{|c|}{ Expt. 4} \\
\hline & & & $\mathrm{K}$ & $\mathrm{R}$ & $\mathrm{K}$ & $\mathrm{R}$ & $\mathrm{K}$ & $\mathrm{R}$ & $\mathrm{K}$ & $\mathrm{R}$ \\
\hline Control & Control & & 0.0 & 0.0 & 0.0 & 0.0 & 0.1 & 0.0 & 0.8 & 0.8 \\
\hline \multirow[t]{2}{*}{16} & 50 & & 0.1 & 0.0 & 0.5 & 0.0 & 0.4 & 0.4 & 2.1 & 0.0 \\
\hline & 100 & & 0.1 & 0.0 & 1.6 & 0.5 & 2.1 & 1.0 & 2.4 & 0.0 \\
\hline \multirow[t]{2}{*}{20} & 50 & & --- & --- & --- & --- & 1.5 & 1.1 & --- & --- \\
\hline & 100 & & --- & --- & --- & --- & 2.9 & 2.1 & --- & --- \\
\hline \multirow{2}{*}{$24-16^{x}$} & 50 & & 0.1 & 0.0 & --- & --- & --- & --- & 2.0 & 0.1 \\
\hline & 100 & & 0.5 & 0.0 & --- & --- & --- & --- & 2.7 & 0.2 \\
\hline \multirow[t]{3}{*}{24} & 50 & & --- & --- & 0.6 & 0.0 & --- & --- & --- & --- \\
\hline & 100 & & --- & --- & 2.6 & 1.2 & --- & --- & --- & --- \\
\hline & & df & \multicolumn{8}{|c|}{ Mean squares } \\
\hline \multicolumn{2}{|l|}{ Heating } & $\overline{1}$ & \multicolumn{2}{|c|}{$0.0397^{x}$} & \multicolumn{2}{|c|}{$276.84^{x}$} & \multicolumn{2}{|c|}{$0.1421^{x}$} & \multicolumn{2}{|c|}{3391} \\
\hline \multicolumn{2}{|l|}{ Heating } & 1 & \multicolumn{2}{|c|}{$0.3431^{\mathrm{w}}$} & \multicolumn{2}{|c|}{$0.9224^{w}$} & \multicolumn{2}{|c|}{$2.0434^{\mathrm{w}}$} & \multicolumn{2}{|c|}{$0.3154^{\mathrm{w}}$} \\
\hline \multicolumn{2}{|l|}{ Error a } & 1 & \multirow{2}{*}{\multicolumn{2}{|c|}{0.1844}} & \multicolumn{2}{|c|}{0.1457} & \multicolumn{2}{|c|}{0.5396} & \multicolumn{2}{|c|}{0.0397} \\
\hline \multicolumn{2}{|l|}{ Lighting } & 4 & \multirow{2}{*}{\multicolumn{2}{|c|}{$0.1376^{\mathrm{NS}, \mathrm{v}}$}} & \multirow{2}{*}{\multicolumn{2}{|c|}{$0.9622^{* *}$}} & & & & \\
\hline Unlighted & hted & 1 & & & & & & & & \\
\hline 50 vs. 100 & $\mathrm{~m}^{-2} \cdot \mathrm{s}^{-1}$ & 1 & & & & & & & & \\
\hline $16 \mathrm{~h}$ vs. 20 & 6 , or $24 \mathrm{~h}$ & 1 & & & & & & & & \\
\hline Error b & & 8 & & & & & & & & \\
\hline Cultivar & & 1 & & & & & & & & \\
\hline Heating $\times c$ & & 1 & & & & & & & & \\
\hline Lighting $\times$ & & 4 & & & & & & & & \\
\hline Heating $\times 1$ & $\mathrm{~g} \times$ cultivar & 4 & & & & & & & & \\
\hline
\end{tabular}

${ }^{2}$ Rated on a scale from 0 to 5 , where $0=$ no tipburn and $5=$ all the leaves were affected.

${ }^{y}$ See Table 1 for the timetable used for the four experiments.

${ }^{x}$ Photoperiod $=24 \mathrm{~h}$ during the first 2 weeks after transplanting and $16 \mathrm{~h}$ during subsequent weeks.

"Insufficient number of degrees of freedom. The mean values appearing in this table have been calculated for the two heating systems combined.

${ }^{v}$ Analysis of variance not performed because of the lack of homogeneity.

Ns, *,**Nonsignificant or significant at $P \leq 0.05$ or 0.01 , respectively.

given off by the catalytic panels and released inside the compartments. Tibbitts and Bottenberg (1976) reported that higher relative humidity during the light period increased relative growth rates of lettuce.

The substantial increases in tipburn during Expt. 2 may be associated with the higher fresh weights of lettuce grown in greenhouses heated with the radiant compared to the air-heated system. Cox et al. (1976) reported that tipburn symptom development was more pronounced in plants characterized by higher growth rates. Higher tipburn ratings of lettuce grown in the greenhouses equipped with catalytic radiant panels compared to the air-heated system may be attributed to higher relative humidity or $\mathrm{CO}_{2}$ levels found in those greenhouses. The increase in relative humidity during the light period (Collier and Tibbitts, 1984) and the use of high $\mathrm{CO}_{2}$ concentrations (Silva and Toop, 1986) are conducive to the development of this disorder.
The heading process is affected by temperature and PPF. Benoît (1987) has reported positive correlations between fresh weight and head firmness in lettuce. According to Benoît (1987), formation of a loose lettuce head characterized by low aerial biomass, results from heavier transpiration and greater water losses. If that is the case, the increased head firmness ratings observed with radiant heating during the second experiment could be attributed to the higher fresh weight of let- 


\section{Crop Production}

Table 5. Percentage of specimens deemed nonmarketable because of tipburn for 'Karlo' (K) and 'Rosana' (R) Boston-type lettuce.

\begin{tabular}{|c|c|c|c|c|c|c|c|c|c|}
\hline \multicolumn{2}{|c|}{ Supplementary lighting treatments } & \multicolumn{8}{|c|}{ Percentage of specimens deemed nonmarketable ${ }^{z}$} \\
\hline \multirow{2}{*}{$\begin{array}{l}\text { Photoperiod } \\
\text { (h) }\end{array}$} & \multirow{2}{*}{$\begin{array}{c}\mathrm{PPF} \\
\left(\mu \mathrm{mol} \cdot \mathrm{m}^{-2} \cdot \mathrm{s}^{-1}\right)\end{array}$} & \multicolumn{2}{|c|}{ Expt. $1^{y}$} & \multicolumn{2}{|c|}{ Expt. 2} & \multicolumn{2}{|c|}{ Expt. 3} & \multicolumn{2}{|c|}{ Expt. 4} \\
\hline & & K & $\mathrm{R}$ & $\mathrm{K}$ & $\mathrm{R}$ & $\mathrm{K}$ & $\mathrm{R}$ & $\mathrm{K}$ & $\mathrm{R}$ \\
\hline Control & Control & 0 & 0 & 0 & 0 & 5 & 0 & 30 & 0 \\
\hline \multirow[t]{2}{*}{16} & 50 & 0 & 0 & 15 & 0 & 5 & 15 & 75 & 0 \\
\hline & 100 & 0 & 0 & 40 & 15 & 65 & 25 & 85 & 0 \\
\hline \multirow[t]{2}{*}{20} & 50 & --- & --- & --- & --- & 40 & 35 & --- & --- \\
\hline & 100 & --- & --- & --- & --- & 85 & 60 & --- & --- \\
\hline \multirow[t]{2}{*}{$24-16^{x}$} & 50 & 0 & 0 & --- & --- & --- & --- & 65 & 0 \\
\hline & 100 & 12 & 0 & --- & --- & --- & --- & 85 & 0 \\
\hline \multirow[t]{2}{*}{$24^{x}$} & 50 & --- & --- & 15 & 0 & --- & --- & --- & --- \\
\hline & 100 & --- & --- & 65 & 25 & --- & --- & --- & --- \\
\hline
\end{tabular}

${ }^{2}$ Lettuce with a tipburn rating $>1$ was regarded as nonmarketable.

ySee Table 1 for the timetable used for the four experiments.

${ }^{x}$ Photoperiod $=24 \mathrm{~h}$ during the first two weeks after transplanting and $16 \mathrm{~h}$ during subsequent weeks.

Table 6. Effects of various light treatments on head firmness for 'Karlo' (K) and 'Rosana' (R) Boston-type lettuce.

\begin{tabular}{|c|c|c|c|c|c|c|c|c|c|c|c|}
\hline \multicolumn{3}{|c|}{ Supplementary lighting treatments } & \multicolumn{9}{|c|}{ Head firmness rating ${ }^{z}$} \\
\hline \multirow{2}{*}{$\begin{array}{l}\text { Photoperiod } \\
\text { (h) }\end{array}$} & \multirow{2}{*}{$\begin{array}{c}\mathrm{PPF} \\
\left(\mu \mathrm{mol} \cdot \mathrm{m}^{-2} \cdot \mathrm{s}^{-1}\right)\end{array}$} & & \multicolumn{2}{|c|}{ Expt. $1^{\mathrm{y}}$} & \multicolumn{2}{|c|}{ Expt. 2} & \multicolumn{2}{|c|}{ Expt. 3} & \multicolumn{3}{|c|}{ Expt. 4} \\
\hline & & & $\mathrm{K}$ & $\mathrm{R}$ & $\mathrm{K}$ & $\mathrm{R}$ & $\mathrm{K}$ & $\mathrm{R}$ & $\mathrm{K}$ & & $\mathrm{R}$ \\
\hline Control & Control & & 1.7 & 1.1 & 0.0 & 0.0 & 1.1 & 0.3 & 3.4 & & $\overline{4.2}$ \\
\hline \multirow[t]{2}{*}{16} & 50 & & 3.4 & 2.6 & 0.4 & 0.4 & 2.7 & 2.3 & 4.7 & & 4.8 \\
\hline & 100 & & 4.1 & 3.5 & 2.6 & 2.1 & 3.8 & 3.8 & 4.7 & & 5.0 \\
\hline \multirow[t]{2}{*}{20} & 50 & & --- & --- & --- & --- & 4.0 & 4.0 & --- & & --- \\
\hline & 100 & & --- & --- & --- & --- & 4.8 & 4.9 & --- & & --- \\
\hline \multirow[t]{2}{*}{$24-16^{x}$} & 50 & & 4.4 & 2.9 & --- & --- & --- & --- & 4.8 & & 4.7 \\
\hline & 100 & & 4.7 & 4.4 & --- & --- & --- & --- & 5.0 & & 4.9 \\
\hline \multirow[t]{3}{*}{$24^{x}$} & 50 & & --- & --- & 1.2 & 1.4 & --- & --- & --- & & --- \\
\hline & 100 & & --- & --- & 3.9 & 3.3 & --- & --- & --- & & --- \\
\hline & & df & \multicolumn{9}{|c|}{ Mean squares } \\
\hline \multicolumn{2}{|l|}{ Heating } & $\overline{1}$ & \multicolumn{2}{|c|}{$2.96^{w}$} & \multicolumn{2}{|c|}{$0.0437^{w}$} & \multicolumn{2}{|c|}{$9.61^{\mathrm{w}}$} & \multicolumn{3}{|c|}{0.0073} \\
\hline \multicolumn{2}{|l|}{ Error a } & 1 & \multicolumn{2}{|c|}{9.97} & \multicolumn{2}{|c|}{0.3769} & \multicolumn{2}{|c|}{2.25} & \multicolumn{3}{|c|}{0.0025} \\
\hline \multicolumn{2}{|c|}{ Lighting } & 4 & \multirow{2}{*}{\multicolumn{2}{|c|}{$139.56^{* * *}$}} & & & \multirow{2}{*}{\multicolumn{2}{|c|}{$117.72^{* * v}$}} & & & \\
\hline \multicolumn{2}{|c|}{ Unlighted vs lighted } & 1 & & & \multicolumn{2}{|c|}{$2.9744^{* * *}$} & & & \multicolumn{3}{|c|}{$34.4450^{* *}$} \\
\hline 50 vs. 100 & $m^{-2} \cdot s^{-1}$ & 1 & \multicolumn{2}{|c|}{$21.86^{* *}$} & \multicolumn{2}{|c|}{$0.2098^{* * *}$} & & & & $0.6250^{\mathrm{Ns}}$ & \\
\hline $16 \mathrm{~h}$ vs. 20 & 6, or $24 \mathrm{~h}$ & 1 & & & & & & & & $0.1000^{\mathrm{Ns}}$ & \\
\hline Error b & & 8 & & & & & & & & 0.0039 & \\
\hline Cultivar & & 1 & & & & & & & & $0.0129^{* *}$ & \\
\hline Heating $\times c$ & & 1 & & & & & & & & $0.0124^{* *}$ & \\
\hline Lighting $\times$ & & 4 & & & & & & & & $0.0103^{* *}$ & \\
\hline Heating $\times 1$ & $\mathrm{~g} \times$ cultivar & 4 & & & & & & & & $0.0013^{\mathrm{Ns}}$ & \\
\hline
\end{tabular}

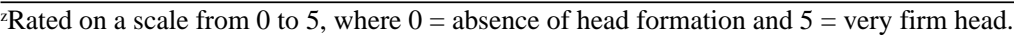

${ }^{y}$ See Table 1 for the timetable used for the four experiments.

xPhotoperiod $=24 \mathrm{~h}$ during the first 2 weeks after transplanting and $16 \mathrm{~h}$ during subsequent weeks.

wInsufficient number of degrees of freedom. The mean values appear in this table.

${ }^{\mathrm{v}}$ Analysis of variance not performed because of the lack of homogeneity.

Ns, **** Nonsignificant or significant at $P \leq 0.01$ or 0.05 , respectively.

tuce plants grown under this type of heating system.

Supplementary lighting and cultivars. 'Rosana' (a long-day cultivar) requires more light than 'Karlo', which may explain why 'Rosana' produced less in the first experiments performed in the autumn and winter. Increases in fresh weight as a result of increasing PPF or lengthening the photoperiod are in agreement with the findings of Koontz and Prince (1986) and Ikeda et al. (1988). Glenn (1984) and Klapwijk (1979) noted the importance of light in determining the production cycle length. The longest production cycle was associated with the time of year when solar radiation was weakest. Our findings, obtained under northerly conditions (lat. $47^{\circ}$ ), tend to substantiate Glenn's (1984) and Klapwijk's (1979) work in Arizona and Holland, respectively.

These findings demonstrate the importance of selecting a cultivar based on its tipburn susceptibility and the time of year. 'Karlo' may be more susceptible because it is a shortday cultivar developed primarily for autumn and winter production. Collier and Tibbitts (1982) reported a genotype $\times$ environment interaction in regards to tipburn development. Our findings confirm Tibbitts and Rao's (1968) and Cox et al.'s (1976) findings; they reported that this disorder developed more rapidly under high-energy lighting conditions - the highest tipburn ratings were associated with treatments involving the high light levels (i.e., those where growth was most rapid). Abrupt changes in environmental conditions (cloudy days alternating with sunny days, for example) occurred during the heading period and may explain the higher incidence of tipburn observed during Expt. 3.

Firmer heads obtained with supplementary lighting or where the natural light level was high demonstrate the importance of light in head development. High-energy light condi- tions promote head formation, but a low light level will result in the formation of a loose head (Benoît, 1987). High temperatures and low light conditions delay head formation (Dullforce, 1968). Benoît (1987) reported that a low light level resulted in some disproportion in midrib development and some tigella lengthening. These anatomical changes resulted in a loose head of lettuce, characterized by comparatively low fresh weight. Our results tend to substantiate Benoît's (1987) observations.

The impact of heating system was most pronounced during December and January. Using catalytic radiant heating rather than the air-heated system resulted in higher biomass and firmer heads, but also fostered tipburn development. This type of heating system seems to be an attractive alternative, provided that $\mathrm{CO}_{2}$ and relative humidity levels can be adequately controlled, thereby reducing the incidence of tipburn. 
Increasing PPF and lengthening the photoperiod resulted in substantial gains in fresh weight, thereby affording a means of reducing the length of the production cycle. The impact of supplementary lighting was more pronounced during those months when natural light levels were low; it resulted in biomass accumulation $\leq 270 \%$ greater and production cycles $\leq 30 \%$ shorter than under natural light. Thus supplementary lighting seems to provide a means of producing more harvests per year. Increasing PPF to $100 \mu \mathrm{mol} \cdot \mathrm{m}^{-2} \cdot \mathrm{s}^{-1}$ resulted in more tipburn when the cultivar possessed lower tipburn tolerance ('Karlo'), when weatherconditions (such as those occurring in spring) were conducive for tipburn, or the photoperiod was 20 or $24 \mathrm{~h}$. Under such conditions, a PPF level of $100 \mu \mathrm{mol} \cdot \mathrm{m}^{-2} \cdot \mathrm{s}^{-1}$ seems to be undesirable, despite the resulting substantial gains in biomass. Having a 24-h photoperiod during the first 2 weeks after transplanting did not result in any tipburn rating increase where PPF was $50 \mu \mathrm{mol} \cdot \mathrm{m}^{-2} \cdot \mathrm{s}^{-1}$, but did produce a substantial gain in biomass in the trial performed in the fall.

This research breaks new ground. The results were obtained under conventional greenhouse production conditions at a northern location. To our knowledge, no data on lettuce relating to continuous lighting and divided photoperiods of 24-16 h have ever been published before. In addition, our findings can be used to develop a growth and harvest date prediction model.

\section{Literature Cited}

Benoît, F. 1987. La culture de laitues pommées lourdes. Revue de l'Agriculture 40(2):895-903

Collier, G.F. and T.W. Tibbitts. 1982. Tipburn of lettuce. Hort. Rev. 4:49-65.

Collier, G.F. and T.W. Tibbitts. 1984. Effects of relative humidity and root temperature on calcium concentration and tipburn development in lettuce. J. Amer. Soc. Hort. Sci. 109:128-131.

Cox, E.F., J.M.T. McKee, and A.S. Dearman. 1976. The effect of growth rate on tipburn occurrence in lettuce. J. Hort. Sci. 51:297-309.

Demers, D.A., J. Charbonneau, and A. Gosselin. 1990. Effets de l'éclairage d'appoint sur la croissance et la productivité du poivron cultivé en serre. Can. J. Plant Sci. 71:587-594.

Dorais, M., A. Gosselin, and M.J. Trudel. 1990. Annual greenhouse tomato production under a sequential intercropping system using supplemental light. Scientia Hort. 45:225-234.

Dullforce, W.M. 1968. Effects of light, temperature and carbon dioxide on the growth of glasshouse lettuce (Lactuca sativa L.). PhD Thesis, Univ. of Nottingham, Nottingham, England.

Glenn, E.P. 1984. Seasonal effects of radiation and temperature on growth of greenhouse lettuce in a high insolation desert environment. Scientia Hort. 22:9-21.

Ikeda, A., S. Nakayama, Y. Kitaya, and K. Yabuki. 1988. Effects of photoperiods, $\mathrm{CO}_{2}$ concentration and light intensity on growth and net photosynthetic rates of lettuce and turnip. Acta Hort. 229:273-282

Klapwijk, D. 1979. Seasonal effects on the cropping-cycle of lettuce in glasshouses during the winter. Scientia Hort. 11:371-377.

Knight, S.L. and C.A. Mitchell. 1983. Enhancement of lettuce yield by manipulation of light and nitrogen nutrition. J. Amer. Soc. Hort. Sci. 108:750-754.

Knight, S.L. and C.A. Mitchell. 1988. Effects of $\mathrm{CO}_{2}$ and photosynthetic photon flux on yield, gas exchange and growth rate of Lactuca sativa 'Waldmann's Green'. J. Expt. Bot. 39:317-328.

Koontz,H.V. and R.P.Prince. 1986. Effect of 16 and 24 hours daily radiation (light) on lettuce growth. HortScience 21:123-124.

Lacroix, L.J., S.J. Westaway, and A.C. Ferguson. 1971. Some plant growth effects under infrared heating in greenhouses. HortScience 6:546-547.

Maaswinkel, R.H.M. and G.W.H. Welles. 1987. Factors affecting head formation of iceberg lettuce (Lactuca sativa L.). Netherlands J. Agr. Sci. 35:37-42.

Reist, A. 1983. Essai de chauffage des serres par radiation infrarouge: Résultats de deux ans d'expérimentation au centre des Fougères. Rev. Suisse Vitic. Arbor. Hort. 15(6):355-357.

Rotz, C.A. and R.D. Heins. 1982. Evaluation of infrared heating system in a Michigan greenhouse. Amer. Soc. Agr. Eng. 25(2):402-407.

Silva, G.H. and E.W. Toop. 1986. Lettuce growth in a nutrient film with carbon dioxide enrichment within a controlled-environment system. Soilless Culture 2(2):41-47.

Tibbitts, T.W. and G. Bottenberg. 1976. Growth of lettuce under controlled humidity levels. J. Amer. Soc. Hort. Sci. 101:70-73.

Tibbitts, T.W. and R.R. Rao. 1968. Light intensity and duration in the development of lettuce tipburn. Proc. Amer. Soc. Hort. Sci. 93:454-461.

Van de Burg, C., E. Enthoven, and G.W.H. Welles. 1981. Growing under infra-red heating. Groenten en Fruit. (37) 15:35-38.

Van Holsteijn, H.M.C. 1980. Growth of lettuce II Quantitative analysis of growth. Meded. Landbouwhogeschool Wageningen 80(13): 1-24 